\title{
PATH ANALYSIS ON THE EFFECT OF SOCIAL CAPITAL ON THE EMPOWERMENT OF PREGNANT WOMEN IN PREECLAMPSIA PREVENTION USING PRECEEDE-PROCEEDE IN KEDIRI EAST JAVA, INDONESIA
}

\author{
KATMINI $^{1 *}$, MURTI B ${ }^{2,3}$, OEPOMO TD ${ }^{3}$, ANANTANYU ${ }^{1}$
}

${ }^{1}$ Study Program of Community Development/Empowerment, Sebelas Maret University, Kota Surakarta, Jawa Tengah, Indonesia. ${ }^{2}$ Master Program of Public Health Sciences, Sebelas Maret University, Kota Surakarta, Jawa Tengah, Indonesia, ${ }^{3}$ Faculty of Medicine, Sebelas Maret University, Surakarta, Kota Surakarta, Jawa Tengah, Indonesia. Email: katminitini@gmail.com

Received: 25 September 2017, Revised and Accepted: 10 January 2018

\section{ABSTRACT}

Objective: Preeclampsia is a common complication of morbidity and mortality in pregnant women, whose death is the leading cause in developing countries. AKI data according to Kediri Health Office 28,187 pregnant women in 2014, with high-risk pregnant women were 5,637, and maternal mothers were 26,906 people, and 13 maternal deaths were recorded as of October 2014. The purpose of this study was to analyze the empowerment of preventing preeclampsia with the increase of antenatal care in pregnant women.

Methods: Type of this study is an observational study with case-control approach. The subjects were chosen by fixed disease sampling, with a ratio of 1:3, a total of 160 subjects. Technique of taking data used a questioner. Data were analyzed by path analysis.

Results: The calculation results have a direct relationship between the use of ante natal care (ANC) ( $b=-0.88 ; 95 \% \mathrm{CI}=-1.66 \mathrm{sd}-0.11$; $\mathrm{p}=0.025)$, maternal age $(\mathrm{b}=-0.93 ; 95 \% \mathrm{CI}=-1.71 \mathrm{sd}-0.14 ; \mathrm{p}=0.020)$, and parity $(\mathrm{b}=-0.94 ; 95 \% \mathrm{CI}=-1.75 \mathrm{sd}-0.14 ; \mathrm{p}=0.021)$ with preeclampsia. There is an indirect relationship between social support $(b=0.75 ; 95 \% \mathrm{CI}=0.10$ to $1.40 ; \mathrm{p}=0.023)$ with preeclampsia through the use of ANC. There is an indirect relationship between trust $(\mathrm{b}=0.82 ; 95 \% \mathrm{CI}=0.04$ to $1.61 ; \mathrm{p}=0.039)$ and social networking ( $\mathrm{b}=0.79 ; 95 \% \mathrm{CI}=0.00$ sd. 1.57 ; $\mathrm{p}=0.048)$; and reciprocal norms $=1.53 ; 95 \% \mathrm{CI}=0.75$ to $2.32 ; \mathrm{p}<0.001$ ) with preeclampsia through social support.

Conclusion: There is a direct and indirect relationship regarding the empowerment of preeclampsia prevention in pregnant women through the theory of social capital and precede proceed.

Keyword: Preeclampsia, Pregnant mothers, Social capital theory, Precede proceed.

(c) 2018 The Authors. Published by Innovare Academic Sciences Pvt Ltd. This is an open access article under the CC BY license (http://creativecommons. org/licenses/by/4. 0/) DOI: http://dx.doi.org/10.22159/ajpcr.2018.v11i4.22766

\section{INTRODUCTION}

The degree of public health of a nation is not only influenced by health factors such as health services and the availability of health facilities and infrastructure but also by economic, education, social environment, heredity, and other factors [1] the degree of public health can be reflected through the maternal mortality rate, infant mortality rate, infant mortality rate and morbidity rate of several diseases, and community nutrition sta [2].

Maternal mortality is one of the indicators to see the degree of women health. Maternal mortality is also one of the targets having been determined in the goal of the third SDGS that is good health. From the results of surveys, it showed that maternal mortality rates have shown decline time by time; however, the efforts to bring into the target goals of SDGs are still ongoing commitment and endeavor [3] National Medium Term Development (RPJMN) is 226 per 100,000 live births. The cause of Maternal Death Maternity is less of public awareness about the health of pregnant women becomes the determinant factor of mortality, although there are still many factors to be considered, especially the factors of preeclampsia also become the cause of maternal mortality in Indonesia. The efforts to reduce maternal mortality need awareness, especially on the empowerment of women and also need an antenatal care check.

The cause of death of the mother can be prevented by doing antenatal care checks. With antenatal care, health workers believe that antenatal care in developing countries reduces the possibility of women who die in pregnancy and childbirth as well as significant maternal morbidity, compared with poor maternal health in developing countries [4]. In a series of health care, antenatal care provides the very important information including health promotion, screening and diagnosis and prevention of illnesses have been established that by applying evidencebased practice in a timely and appropriate manner of antenatal care can save the life of pregnant women [5] recommendation on antenatal care for positive pregnancy experience [6]. Antenatal care plays an important role in reducing maternal mortality and morbidity by detecting early risk factors to make effective interventions on time and by relating pregnant women with planned delivery with skilled birth attendants. However, the use of antenatal care services for pregnant women is problematic in many low-income countries [7]. If there is one high-risk factor of pregnant women in pregnancy, early preventive measures can be taken so that the risk of the death can be reduced quickly and precisely [8]. A number of elements of treatment are advised that require more monitoring and contact with health workers with appropriate expertise [9]. In addition, women should also be given accurate and relevant information and emotional support to reduce anxiety and pressure from high-risk pregnancies [10].

Formal and informal social support on the health of pregnant women is also very important for their health [11]. It can be in the form of information through calling from health workers to pregnant women so that antenatal care examination can be fulfilled [12]. Early detection of risk factors for complications is an activity to find pregnant women with risk factors and complications [13]. Every pregnancy is normal for a woman in her rehabilitation process, but sometimes complication 
is happening, so that the adequate handling can be done as early as possible. This is the key of success in reducing maternal mortality and infant mortality [14].

The health promotion efforts as in Decree of the Minister of Health RI No.1193/MENKES/SK/X/2004 defines the promotion of health as an effort to increase the ability of the community through learning from, by, for and with the community, so that they can help themselves, as well as developing community-driven activities, as the local social culture and supported by health-minded public policies.

The purpose of this study is to formulate health promotion model to prevent preeclampsia in pregnant women in Kediri East Java.

\section{METHODS}

\section{Ethical approval}

This study received approval from the Ethics Committee of the Faculty of Medicine, Sebelas Maret University. Administrative Clearance was obtained from the ministry of internal affairs Republic of Indonesia and National Unity and Community protection office (Bakesbangpolinmas), at provincial and district level. Informed consent from respondent before the research.

This type of research is an observational study with case-control study approach [15]. The subjects were chosen on a fixed disease sampling basis, with a ratio of 1: 3 for case subjects (pregnant women with preeclampsia) and control (without preeclampsia), a total of 160 subjects. Techniques of data collection used questionnaires with validity and reliability tests of research instruments then calculated so that the resulting figure on the overall results of the questionnaire has Alpha Cronbach $>0.60$. Data were analyzed with Path Analysis using Stata 13 program.

\section{RESULTS AND DISCUSSION}

\section{Bivariate analysis}

The variables in the research are social networking, trust, mutual norm, social support, antenatal care, age, parity, and preeclampsia. The method used is Chi-square test (Table 1).

\section{Path analysis}

Specification model will be described as the relationship between variables to be studied. In this study, there are eight measurable variables (i.e., observed variables); social networks, trust, reciprocal norms, social support, antenatal care, age, parity, and preeclampsia (Fig. 1).

Table 2 summarizes that the calculation results have a direct relationship between the use of ante natal care (ANC) ( $b=-0.88$; CI 95\% $=-1.66 \mathrm{sd}-0.11 ; \mathrm{p}=0.025)$, maternal age $(\mathrm{b}=-0.93 ; 95 \% \mathrm{CI}=-1.71 \mathrm{sd}$ $-0.14 ; \mathrm{p}=0.020)$, and parity $(\mathrm{b}=-0.94 ; 95 \% \mathrm{CI}=-1.75 \mathrm{sd}-0.14 ; \mathrm{p}=0.021)$ with preeclampsia. Moreover, there is an indirect relationship between social support $(\mathrm{b}=0.75 ; 95 \% \mathrm{CI}=0.10-1.40 ; \mathrm{p}=0.023)$ and preeclampsia through the use of ANC. Moreover, there is also an indirect relationship between trust $(\mathrm{b}=0.82 ; 95 \% \mathrm{CI}=0.04-1.61 ; \mathrm{p}=0.039)$ and social networking ( $b=0.79 ; 95 \% \mathrm{CI}=0.00 \mathrm{sd} 1.57 ; \mathrm{p}=0.048)$; and reciprocal (norms $=1.53 ; 95 \% \mathrm{CI}=0.75-2.32 ; \mathrm{p}<0.001$ ) with preeclampsia through social support.

The results of the analysis indicate that there is a positive relationship between social duties with the use of antenatal care and the use of antenatal care has a negative relationship with the incidence of preeclampsia. Pierce [16] states that human relationships mean a lot to him as an individual. It can be said that we are at least partially interpreted through whom we know more as the bonds between humans also serve as limiting for broader social structures. The central idea of social capital is that social networks are a valuable asset.

Low social support to pregnant women to use antenatal care makes pregnant women feel unperturbed and helpless. Hence, in cases some of the pregnant women do not used antenatal care well. Therefore, social support is needed to change the behavior of pregnant women to make changes in health behavior, especially in the use of antenatal care services so that the risk of pregnancy can be detected earlier. The study by Katapodi [17] says that social support is linked to a focus on screening and adherence in routine screening for health services. [18], who said that the change in behavior toward health measures is dependent on the support, while one is from their family, thus it will be a boost for pregnant women to reuse antenatal care (ANC) well. In ANC services it is also necessary to have an education campaign to raise awareness about risk factors, natural history of compilation and also treatment. Patients who are disobedient and complicated may be asked to share their experiences voluntarily; audiovisual is helpful in the delivery of information [19]. To increase maternal awareness also need counseling services to educate mothers about the benefits of ANC. The skills of health workers in providing appropriate counseling are also important. Use of IEC materials such as leaflets or posters can be done to provide information to pregnant women and family members about the importance of ANC [20].

Preeclampsia is more common in the first pregnancy compared with subsequent pregnancies. This is due to the fact that in pregnancy, the

Table 1: Results of bivariate analysis

\begin{tabular}{lllll}
\hline $\begin{array}{l}\text { Independent } \\
\text { variable }\end{array}$ & Value OR & Value p & \multicolumn{2}{l}{ CI (95\%) } \\
\cline { 3 - 5 } & & & $\begin{array}{l}\text { Upper } \\
\text { limit }\end{array}$ & $\begin{array}{l}\text { Lower } \\
\text { limit }\end{array}$ \\
\hline Social networking & 0.44 & 0.027 & 0.21 & 0.92 \\
Trust & 0.26 & 0.001 & 0.12 & 0.57 \\
Mutual norm & 0.34 & 0.005 & 0.16 & 0.73 \\
Social support & 0.27 & 0.002 & 0.11 & 0.63 \\
Age & 0.32 & 0.002 & 0.15 & 0.67 \\
The use of ANC & 0.40 & 0.013 & 0.19 & 0.84 \\
Parity & 0.30 & 0.002 & 0.14 & 0.66 \\
\hline
\end{tabular}

ANC: Antenatal care

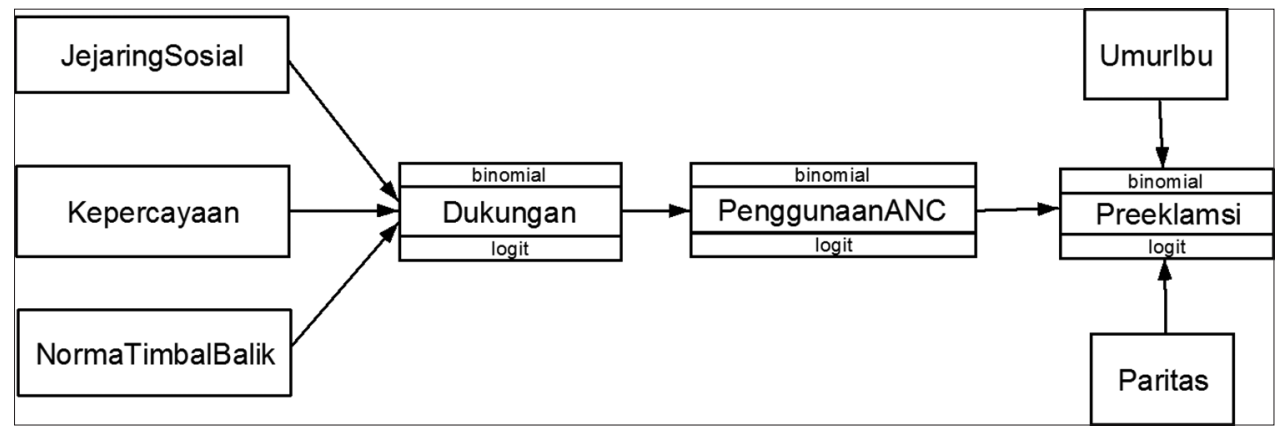

Fig. 1: Conformity of path analysis model 
Table 2: Results of the empowerment of path analysis of preeclampsia prevention in pregnant women through social capital theory and precede proceed

\begin{tabular}{|c|c|c|c|c|}
\hline \multirow[t]{2}{*}{ The relationship between dependent and independent variable } & \multirow[t]{2}{*}{ Path Koef (B) } & \multicolumn{2}{|l|}{ CI 95\% } & \multirow[t]{2}{*}{$\mathbf{p}$} \\
\hline & & Lower limit & Upper limit & \\
\hline \multicolumn{5}{|l|}{ Direct } \\
\hline \multicolumn{5}{|l|}{ Preeclampsia $\leftarrow$} \\
\hline The use of ANC ( $\geq 32)$ & -0.88 & -1.66 & -0.11 & 0.025 \\
\hline Mother's age (20-35 tahun) & -0.93 & -1.71 & -0.14 & 0.020 \\
\hline Parity $(\geq)$ & -0.94 & -1.75 & -0.14 & 0.021 \\
\hline \multicolumn{5}{|l|}{ Indirect } \\
\hline \multicolumn{5}{|l|}{ The use of ANC $\leftarrow$} \\
\hline Social support $(\geq 20)$ & 0.75 & 0.10 & 1.40 & 0.023 \\
\hline \multicolumn{5}{|l|}{ Social support $\leftarrow$} \\
\hline Trust $(\geq 9)$ & 0.82 & 0.04 & 1.61 & 0.039 \\
\hline Social networking $(\geq 6)$ & 0.79 & 0.00 & 1.57 & 0.048 \\
\hline Reciprocal norm $(\geq 8)$ & 1.53 & 0.75 & 2.32 & $<0.001$ \\
\hline Number observation & 160 & & & \\
\hline Log likelihood & -274.23 & & & \\
\hline AIC & 568.47 & & & \\
\hline BIC & 599.23 & & & \\
\hline$\leftarrow$ Connected to & & & & \\
\hline
\end{tabular}

first blocking of antibodies to the placenta antigen is not complete, which is more perfect in the next stage. In theory, primigravida is more at risk for preeclampsia than multigravidae, because preeclampsia usually occurs in women first exposed to chorionic villi. This occurs because the immunologic mechanism of the formation of blocking antibody performed by HLA-G (human leukocyte antigen G) against the placental antigen is not completely formed, so the process of trophoblast implantation to the mother's decidual is disturbed. Primigravida is also susceptible to stress in the face of labor that will stimulate the body to release cortisol.

\section{CONCLUSION}

This research suggests that social networking, social support, trust, high reciprocal norms need to be improved so that the individual feels stronger support and is able to perform ANC well. Support is material, informational support and support instrumental, the higher the support of the community in pregnant women, the higher the health behavior of pregnant women. Apart from the support, it is necessary to counsel health about the dangers of pregnancy risk including the originator of risk pregnancy can also be caused due to age and also parity.

Subsequent research is suggested to develop this research and refine the model through field trials so that it can assess and apply theories of health promotion models.

\section{ACKNOWLEDGMENT}

We would like to thank Study Program of Community Development/Empoworment, Sebelas Maret University Surakarta. For this technical assistence in this Study. We are indebted tahnks to Health Office From Kediri Regency and all respondents who participared in this Study

\section{REFERENCES}

1. Kementerian Kesehatan RI. Pusat Data dan Informasi. Jakarta Selatan: Kementerian Kesehatan RI; 2014.

2. Dinas Kesehatan Kabupaten Kediri; 2015. Available from: http://www. dinkes.kedirikab.go.id.

3. Budiantoro S. Angka Kematian Ibu (AKI) Melonjak, Indonesia Mundur 15 Tahun, Prakarsa, 2013. p. 2. Available from: http://www.theprakarsa. org/new/ck_uploads/files/Prakarsa
Available from: http://www.theprakarsa.org/new/ck uploads/files/ Prakarsa Policy_Oktober_Rev3-1.pdf.

4. Rooney C. Antenatal Care and Maternal Health: How Effective is it? A Review of the Evidence. Geneva: World Health Organization; 1992.

5. WHO. Recommendation on Antenatal Care for Positive Pregnancy Experience. Geneva: WHO; 2016.

6. Phillimore J. Migrant maternity in an era of superdiversity: New migrant's access to and experience of, antenatal care in the West Midlands, UK. J Soc Sci Med 2016;148:152-9.

7. Manithip C. Quality and Utilisation of Antenatal Care Services in Rural Lao PDR. Stockholm: Chanthanom Manithip; 2012.

8. Bricker L. Optimal antenatal care for twin and triplet pregnancy: The evidence base. J. Best Pract Res Clin Obstet Gynaecol 2014;1:305-17.

9. Bele SC, Rrugia A, Doko A, Cafka M, Abazaj A, Petrela E. The cardiac adaptations in acute pressure overload during pregnancy hypertension. Eur J Prev Cardiolvol 2014;2:11-2.

10. Bele S, Rrugia A, Petrela E, Bare T. Pregnancy hypertension and the risk of cardiovascular disease. J Perinat Med 2015;1:1-10.

11. Chou FH, Avant KC, Kuo SH, Fetzer SJ. Relationships between nausea and vomiting, perceived stress, social support, pregnancy planning, and psychosocial adaptation in a sample of mothers: A questionnaire survey. Int J Nurs Stud 2008:45:1185-91.

12. SCL. Social Support, Care Coordination and Pregnancy Outcomes. Social Support, Care Coordination and Pregnancy Outcomes; 1995. Available from: http://www.search.ebscohost.com/login.aspx?direct=t rue $\& \mathrm{db}=\operatorname{cin} 20 \& \mathrm{AN}=109873156 \&$ site $=$ ehost-live .

13. Pauli JM, Repke JT. Short-Them and Long-Term Implications; 2015. Available from: http://www.Obsgyn.theclinics.com.

14. Bele S, Rrugia A, Doko A, Cafka M, Abazaj A, Petrela E. Does pregnancy hypertension affect the healthy heart of women. Eur J Prev Cardiol 2013;1:1-5.

15. Damayanti VS. Metode Penelitian Pendidikan Bahasa. Bandung: PT Remaja Rosdakaya; 2009.

16. Kail and Cavanaugh. Human Development: A Life Span View. USA: Wadswoth; 2000.

17. Katapodi MC. Perceived breast cancer risk: Heuristic reasoning and search for a dominance structure. Soc Sci Med 2005;60:421-32.

18. Baron RA. Psiokologi sosial. In: Psiokologi Sosial. Jakarta: Erlangga; 2003.

19. Sulistiyowatiningsih E, Herawati M. A multicenter study treatment adherence of hypertension focused on primary health care in Indonesia. Asian J Pharm Clin Res 2017;2017:24-7.

20. Titaley RC, Rahayu E, Damayanti R, Dachlia D, Sartika DA, Ismail A, et al. Assosiation between knowledge and complication of taking iron/folid acid supplement during pregnancy. Asian J Pharm Clin Res 2017;10:181. 